ҚАЗАҚСТАН РЕСПУБЛИКАСЫ

ҰЛТТЫҚ ҒЫЛЫМ АКАДЕМИЯСЫНЫН

АБАЙ АТЫНДАҒЫ ҚАЗАҚ ҰЛТТЫҚ

ПЕДАГОГИКАЛЫҚ УНИВЕРСИТЕТІНІҢ

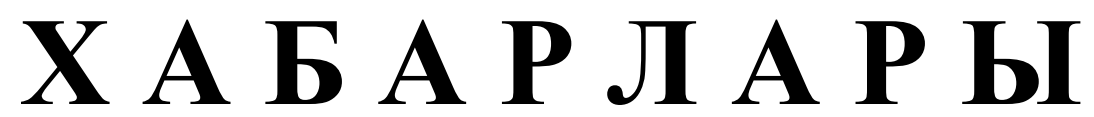

\section{ИЗВЕСТИЯ}

НАЦИОНАЛЬНОЙ АКАДЕМИИ НАУК РЕСПУБЛИКИ КАЗАХСТАН

КАЗАХСКИЙ НАЦИОНАЛЬНЫЙ

ПЕДАГОГИЧЕСКИЙ УНИВЕРСИТЕТ ИМ. АБАЯ

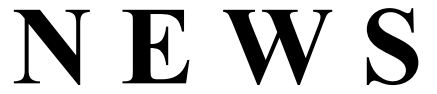

OF THE NATIONAL ACADEMY OF SCIENCES OF THE REPUBLIC OF KAZAKHSTAN

ABAY KAZAKH NATIONAL PEDAGOGICAL UNIVERSITY

ҚОҒАМДЫҚ ЖӘНЕ ГУМАНИТАРЛЫҚ ҒЫЛЫМДАР СЕРИЯСЫ

СЕРИЯ ОБЩЕСТВЕННЫХ И ГУМАНИТАРНЫХ НАУК

$\checkmark$

SERIES OF SOCIAL AND HUMAN SCIENCES

$$
5 \text { (321) }
$$

КЫРКУЙЕК - КАЗАН 2018 ж.

СЕНТЯБРЬ - ОКТЯБРЬ 2018 Г.

SEPTEMBER - OCTOBER 2018

1962 ЖЫЛДЫҢ ҚАНТАР АЙЫНАН ШЫҒА БАСТАҒАН

ИЗДАЕТСЯ С ЯНВАРЯ 1962 ГОДА

PUBLISHED SINCE JANUARY 1962

ЖЫЛЫНА 6 РЕТ ШЫҒАДЫ

ВЫХОДИТ 6 РАЗ В ГОД

PUBLISHED 6 TIMES A YEAR 
Ба с ре дактор

ҚР ҰҒА кұрметті мүшесі

Балықбаев Т.O.

Р е д а ц и я а лқ а сы:

экон. ғ. докторы, проф., ҚР ҰҒА академигі Баймұратов У.Б.; тарих ғ. докторы, проф., ҚР ҰҒА академигі Байпақов К.М.; филос. ғ.докторы, проф., ҚР ҰҒА академигі Есім Г.Е.; фил. ғ. докторы,, проф., ҚР ҰҒА академигі Қирабаев С.С.; эк. ғ. докторы, проф., ҚР ҰҒА академигі Кошанов А.К.; эк.ғ. докторы, проф., ҚР ҰҒА академигі Нәрібаев К.Н. (бас редактордың орынбасары); филос. ғ.докторы, проф., ҚР ҰҒА академигі Нысанбаев А.Н.; заң ғ. докторы, проф., ҚР ҰҒА академигі Сәбікенов С.Н.; заң ғ. докторы, проф., ҚР ҰҒА академигі Сүлейменов М.К.; эк. ғ. докторы, проф., ҚР ҰҒА академигі Сатыбалдин С.С.; тарих ғ. докторы, проф., ҚР ҰҒА академик Әбжанов Х.М.; тарих ғ. докторы, проф., ҚР ҰҒА корр. мүшесі Әбусеитова М.Х.; тарих ғ. докторы, проф., ҚР ҰҒА академик Байтанаев Б.А.; филол. ғ. докторы, проф., ҚР ҰҒА корр. мүшесі Жақып Б.А.; фил. ғ. докторы, проф., академик НАН РК Қалижанов У.К.; филол. ғ. докторы, проф., ҚР ҰҒА академик Қамзабекұлы Д.; тарих ғ. докторы, проф., ҚР ҰҒА академик Қожамжарова Д.П.; тарих ғ. докторы, проф., ҚР ҰҒА академик Койгелдиев М.К.; фил. ғ. докторы, проф., ҚР ҰҒА корр. мүшесі Кұрманбайұлы Ш.; тарих ғ. докторы, проф., ҚР ҰҒА корр. мүшесі Таймағанбетов Ж.К.; социол. ғ. докторы, проф., ҚР ҰҒА корр. мүшесі Шәукенова 3.К.; фил. ғ. докторы, проф., КР ҰҒА корр. мүшесі Дербісәлі А.; саяси. ғ. докторы, проф., Бижанов А.К., тарих ғ. докторы, проф., Кабульдинов 3.Е.; фил. ғ. докторы, проф., ҚР ҰҒА корр мүшесі Қажыбек Е.3.

\section{Р едакция ке н е с i:}

Молдова Республикасының ҰҒА академигі Белостечник Г. (Молдова); Әзірбайжан ҰҒА академигі Велиханлы Н. (Азербайджан); Тәжікстан ҰҒА академигі Назаров Т.Н. (Тәжікстан); Молдова Республикасының ҰҒА академигі Рошка А. (Молдова); Молдова Республикасының ҰҒА академигі Руснак Г. (Молдова); Әзірбайжан ҰҒА корр. мүшесі Мурадов Ш. (Әзірбайжан); Әзірбайжан ҰҒА корр. мүшесі Сафарова 3. (Әзірбайжан); э. ғ. д., проф. Василенко В.Н. (Украина); заң ғ. докт., проф. Устименко В.А. (Украина)

«Қазақстан Республикасы Ұлттық ғылым академиясының Хабарлары. Қоғамдық және гуманитарлық ғылымдар сериясы». ISSN 2224-5294

Меншіктенуші: «Қазақстан Республикасының Ұлттық ғылым академиясы» РҚБ (Алматы қ.)

Қазақстан республикасының Мәдениет пен ақпарат министрлігінің Ақпарат және мұрағат комитетінде 30.04.2010 ж. берілген № 10894-Ж мерзімдік басылым тіркеуіне қойылу туралы куәлік

Мерзімділігі: жылына 6 рет.

Тиражы: 500 дана.

Редакцияның мекенжайы: 050010, Алматы қ., Шевченко көш., 28, 219 бөл., 220, тел.: 272-13-19, 272-13-18, http://nauka-nanrk.kz. social-human.kz

(C) Қазақстан Республикасының Ұлттық ғылым академиясы, 2018

Типографияның мекенжайы: «Аруна» ЖК, Алматы қ., Муратбаева көш., 75. 
Главный редакто $p$

Почетный член НАН РК

T.O. Балыкбаев

Р е дак ци онн а я коллег и я:

докт. экон. Н., проф., академик НАН РК У.Б. Баймуратов; докт. ист. н., проф., академик НАН РК К.М. Байпаков; докт. филос. Н., проф., академик НАН РК Г.Е. Есим; докт. фил. Н., проф., академик НАН РК С.С. Кирабаев; докт. экон. Н., проф., академик НАН РК А.К. Кошанов; докт. экон. Н., проф., академик НАН РК К.Н. Нарибаев (заместитель главного редактора); докт. филос. н., проф., академик НАН РК А.Н. Нысанбаев; докт. юр. Н., проф., академик НАН РК С.Н. Сабикенов; докт. юр. н., проф., академик НАН РК М.К. Сулейменов; докт. экон. Н., проф., академик НАН РК С.С. Сатубалдин; докт. ист. н., проф., академик НАН РК Х.М. Абжанов; докт. ист. н., проф., чл.-корр. НАН РК М.Х. Абусеитова; докт. ист. н., проф., академик НАН РК Б.А. Байтанаев; докт. фил. н., проф., чл.-корр. НАН РК Б.А. Жакып; докт. фиолол. н., проф., академик НАН РК У.К. Калижанов; докт. фил. н., проф., академик НАН РК Д. Камзабекулы; докт. ист. н., проф., академик НАН РК Д.П. Кожамжарова; докт. ист. н., проф., академик НАН РК М.К. Койгельдиев; докт. филол. н., проф., чл.-корр. НАН РК Ш. Курманбайулы; докт. ист. н., проф., чл.корр. НАН РК Ж.К. Таймаганбетов; докт. социол. н., проф., чл.-корр. НАН РК З.К. Шаукенова; д. филол. н., проф., чл.-корр. НАН РК А. Дербисали; доктор политических наук, проф., Бижанов А.К.; доктор ист. наук, проф., Кабульдинов 3.Е.; доктор филол. н., проф., член-корр. НАН РК Қажыбек Е.3.

Р е дак ци онны й с ов е т

академик НАН Республики Молдова Г. Белостечник (Молдова); академик НАН Азербайджанской Республики Н. Велиханлы (Азербайджан); академик НАН Республики Таджикистан Т.Н. Назаров (Таджикистан); академик НАН Республики Молдова А. Рошка (Молдова); академик НАН Республики Молдова Г. Руснак (Молдова); чл.-корр. НАН Азербайджанской Республики Ш. Мурадов (Азербайджан), член-корр. НАН Азербайджанской Республики 3.Сафарова (Азербайджан); д. э. н., проф. В.Н. Василенко (Украина); д.ю.н., проф. В.А. Устименко (Украина)

Известия Национальной академии наук Республики Казахстан. Серия общественных и гуманитарных наук. ISSN 2224-5294

Собственник: РОО «Национальная академия наук Республики Казахстан» (г. Алматы)

Свидетельство о постановке на учет периодического печатного издания в Комитете информации и архивов

Министерства культуры и информации Республики Казахстан № 10894-Ж, выданное 30.04.2010 г.

Периодичность 6 раз в год

Тираж: 500 экземпляров

Адрес редакции: 050010, г. Алматы, ул. Шевченко, 28, ком. 219, 220, тел. 272-13-19, 272-13-18, www:nauka-nanrk.kz / social-human.kz

(C) Национальная академия наук Республики Казахстан, 2018 г.

Адрес типографии: ИП «Аруна», г. Алматы, ул. Муратбаева, 75

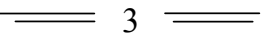


Chief Editor

\section{Honorary member of NAS RK \\ Balykbayev T.O}

Editorial board:

Doctor of economics, prof, academician of NAS RK Baimuratov U.B.; doctor of history, prof, academician of NAS RK Baipakov K.M.; doctor of philosophy, prof, academician of NAS RK Esim G.E.; doctor of philology, prof, academician of NAS RK Kirabayev S.S.; doctor of economics, prof, academician of NAS RK Koshanov A.K.; doctor of economics, prof, academician of NAS RK Naribayev K.N. (deputy editor-in-chief); doctor of philosophy, prof, academician of NAS RK Nyssanbayev A.N.; doctor of law, prof, academician of NAS RK Sabikenov S.N.; doctor of law, prof, academician of NAS RK Suleymenov M.K.; doctor of economy, prof, academician of NAS RK Satybaldin S.S.; doctor of history, prof, academician of NAS RK Abzhanov H.M; doctor of history, prof, corresponding member of NAS RK Abuseitova M.H.; doctor of history, prof, academician of NAS RK Baitanaev B.A.; doctor of philology, prof, corresponding member of NAS RK Zhakyp B.A.; doctor of philology, prof, academician of NAS RK Kalizhanov U.K.; doctor of philology, prof, academician of NAS RK Hamzabekuly D.; doctor of history, prof, academician of NAS RK Kozhamzharova D.P.; doctor of history, prof, academician of NAS RK Koigeldiev M.K.; doctor of philology, prof, corresponding member of NAS RK Kurmanbaiuly Sh.; doctor of history, prof, academician of NAS RK Taimaganbetov J.K.; doctor of sociology, prof, corresponding member of NAS RK Shaukenova Z.K.; doctor of philology, prof, corresponding member of NAS RK Derbisali A.; doctor of political science, prof Bizhanov A.K; doctor of History, prof Kabuldinov Z.E.; doctor of philology, prof, corresponding member of NAS RK Kazhybek E.Z.

\section{Editorial staff:}

Academician NAS Republic of Moldova Belostechnik.G (Moldova); Academician NAS Republic of Azerbaijan Velikhanli N. (Azerbaijan); Academician NAS Republic of Tajikistan Nazarov T.N. (Tajikistan); Academician NAS Republic of Moldova Roshka A. (Moldova) Academician NAS Republic of Moldova Rusnak G. (Moldova); Corresponding member of the NAS Republic of Azerbaijan Muradov Sh. (Azerbaijan); Corresponding member of the NAS Republic of Azerbaijan Safarova Z. (Azerbaijan); Associate professor of Economics Vasilenko V.N. (Ukraine), Associate professor of Law Ustimenko V.A. (Ukraine)

News of the National Academy of Sciences of the Republic of Kazakhstan. Series of Social and Humanities. ISSN 2224-5294

Owner: RPA "National Academy of Sciences of the Republic of Kazakhstan" (Almaty)

The certificate of registration of a periodic printed publication in the Committee of information and archives of the Ministry of culture and information of the Republic of Kazakhstan N 10894-Ж, issued 30.04.2010

Periodicity: 6 times a year

Circulation: 500 copies

Editorial address: 28, Shevchenko str., of. 219, 220, Almaty, 050010, tel. 272-13-19, 272-13-18, www:nauka-nanrk.kz / social-human.kz

(C) National Academy of Sciences of the Republic of Kazakhstan, 2018

Address of printing house: ST "Aruna", 75, Muratbayev str, Almaty 
N E W S

OF THE NATIONAL ACADEMY OF SCIENCES OF THE REPUBLIC OF KAZAKHSTAN

SERIES OF SOCIAL AND HUMAN SCIENCES

ISSN 2224-5294

https://doi.org/10.32014/2018.2224-5294.26

Volume 5, Number 321 (2018), $152-159$

UDK 342.7(574)

D.A. Ospanova, D.M. Baimakhanova

Al-Farabi Kazakh National University, Kazakhstan, Almaty

dina 405@mail.ru; azizkhan_0606@mail.ru

\title{
ADMINISTRATIVE AND LEGAL SUPPORT OF DIGITALIZATION OF PUBLIC SERVICES IN THE CONTEXT OF THE DEVELOPMENT OF CYBER SPACE IN THE REPUBLIC OF KAZAKHSTAN
}

\begin{abstract}
The purpose of the work is to analyze the legal nuances of e-government development in the Republic of Kazakhstan; determination of the periodization of the development of the formation and activities of egovernment; definition of features of electronic document circulation through electronic government. The urgency of the article is determined by the following factors: the acceleration of digital modernization in Kazakhstan under the application of global informatization leads to the transition to electronic document circulation; Increasing the efficiency of the Kazakh government through the introduction of information technology; (Non-commercial jointstock company "State Corporation Government for Citizens "); the task is to accelerate the economic and political modernization of Kazakhstan's society through the extensive use of information technologies, as well as theoretical and practical interest in studying the potential benefits of e-government and electronic document management.
\end{abstract}

Key words: electronic government, electronic digital signature, electronic document management, state services, digitalization, legal regulation.

\section{Introduction}

In modern society, social relations are modernized under the influence of information and communication technologies. The changes are also related to a number of aspects of the functioning of the state. The electronic state must be understood as a form of organization of the activities of public authorities in the virtual space, which, due to the widespread use of information and communication technologies, optimizes public administration.

One of the main features of the electronic state is "virtualization (duplication) of objects of reality, that is, the transfer of their analogues to the electronic form".

The concepts of "e-government", "e-government" and "electronic state" are often used as synonyms. At the same time, there is a difference between these concepts. So, Tikhonova S.V. considers the electronic state as "a new stage in the development of a constitutional state, a new way of organizing public power, for which the transformation of all three branches of state power is characteristic. Legislative branch is represented by electronic lawmaking and electronic parliaments, executive by electronic government, judicial - by electronic justice (from Tikhonova, 2013). In turn, V.E. Chebotarev and E.I. Konovalov as electronic components of the electronic state allocate "electronic government and electronic democracy". In the work of N.N. Kovaleva. the course of a comparative analysis of the terms "electronic state" and "electronic government", the necessity of refusing to use these terms as synonyms is proved. In this regard, the study of the theoretical and legal aspects of the formation of the institutions of the "electronic state" and "electronic government" in the conditions of the information society development is of "practical importance in conducting linguistic and legal expertise of normative legal acts in the norm-setting process in the field of legal regulation of relations in the information environment".

E-government is a system of government, interaction of power structures among themselves, with citizens and enterprises using information technology (which in theory should reduce red tape and, conversely, increase the transparency of government activities). 
E-government has several definitions, but the simplest terms, it includes those management processes in which information and communication technologies (ICTs) play an active role in delivering management-related products and services.

The use of ICT in management can lead to one or more of the following 4 key changes: improving the quality and standards of existing management products and services, providing new public services and products to citizens / users, increasing the participation of citizens / users in deciding which products and services should be provided and how to bring new layers of society into the sphere of public administration, including those that are more inclined to remain out of attention, namely the poor, illiterate, with limited physical abilities, migrants and internally displaced persons.

Thus, e-government does not simply mean the digitization or automation of existing public services. Instead, e-government is a tool for transforming government services so that they can be delivered more efficiently and monotonously to all segments of society.

\section{The main part}

The governments of the world's leading countries are committed to building the capacity for the development of the digital economy, conducting research and testing new technology. They not only improve legislation, but also create and develop a digital infrastructure and an advanced knowledge and skills base.

Many leaders in the field of high technologies note that the qualitative development of the digital sector was preceded by a long history: from the creation of computer technology and the development of the World Wide Web to the formation of artificial intelligence. Among such leading countries are the United Kingdom, the United States, Singapore and the Republic of Korea.

Great Britainexample. As part of the development of public administration and public services, the UK uses digital technology to transform its services and systems in order to make them easier and cheaper. The Cabinet of Ministers of the United Kingdom in 2011 created a service for combining state digital services, which is engaged in the State Digital Service (SDS). According to the GCC, the transfer of public services to electronic format can save the Government of the UK from 1.7 million to 1.8 million pounds a year.

It was expected that by 2015 all the following types of services will be digitized:

- Services provided by the National Vocational Training Service. The translation of information about candidates collected by the Service into an electronic form will simplify the process of finding vacancies and applying for a job. On the other hand, employers will be able to post vacancies and select suitable employees.

- Independent determination of the amount of tax: a new electronic service will simplify the calculation of the amount of tax for ordinary citizens.

- Services provided by the Information Disclosure Service and deprivation of the right to hold certain positions (DBS). More and more young people are interested in volunteer programs, however, in order to be eligible to participate in these programs, every Briton needs to pass a DBS service check. Translation into an electronic format of all the information collected by this DBS service will allow citizens to apply for volunteer programs without unnecessary paperwork.

- Intellectual property: an electronic service will allow large and small entrepreneurs to quickly register and control patents, trademarks and projects online, thanks to the Office for the Protection of Intellectual Property Rights.

SDS developed the Government Transformation Strategy until 2020, which consists of the following components:

1. Transformation of all public services with a view to further enhancing their convenience for citizens, businesses and users of the public sector.

2. Complete transformation of departments will result in flexible implementation of targets, improve cross-channel provision of services, and increase efficiency.

3 . The internal transformation of the government, which does not necessarily externally affect public services, but is vital for better interaction between parts of the state apparatus and for the implementation of "digital" transformations.

The USA example. The US Digital Service (USDS) was established in 2014 to address the most important public digital services of the federal government. USDS is focused not only on how American people can interact with their government on the Internet.

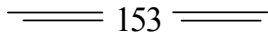


As of June 2017, USDS has established the appropriate teams in seven federal agencies: the Department of Defense, the Department of Veterans Affairs, the Department of Homeland Security, the Department of Health and Human Services, the Department of Education, the Office of General Services and the Small Business Administration.

The US pursues a policy to develop the digital service in the following areas: modernization of immigration policy, benefits for veterans, health care, education, taxpayer data, defense system of imports and exports.

Singapore example. In order to most effectively serve its people, the Government of Singapore has taken the following steps:

1. A 10-year "Basic plan for ICT 21" was developed, according to which, until 2021, Singapore's strategic goal is to prepare the state-city for the information society of the future.

2. The practice of conducting electronic elections and censuses of the population is being introduced and improved.

3. The Ministry of Justice and its structural subdivisions are working to develop a "roadmap" for the creation of a three-dimensional land information system based on geospatial data.

4. A remote monitoring and evaluation system was created (i) the status of patients (telemedicine), (ii) electronic transactions, and (iii) the effectiveness of e-government.

In 2017, the Government of Singapore embarked on the following innovations in terms of digitalization: books.

1. Re-equipment of libraries in order to make it convenient for readers to search and read electronic

2. The Government has expanded the HomeAccessProgram, which allows low-income households access to affordable digitalization services.

3. Electronic services will be improved through the GovTech national platform. GovTech will use advanced services, such as "AskJamie" - virtual assistant.

In 2017, Singapore continued to implement the SmartNation initiative and conducted work on the development of digital, information and cyber-safe SmartNation applications.

The experience of Korea. In terms of informatization and the development of e-government in Korea has the highest rates in the world. In the ranking of E-participationIndex, Korea ranked 1st in 2010, 2012 and 2014.

In 2011, the formulated Smart Electronic Government (Smart E-GovPlan) Plan translated the computer e-government into a mobile e-government using smartphones and tablets.

Since 2013, Korea is guided by the strategic direction of "Government 3.0", within which there are three strategic directions: Government oriented to services; Transparent Government; The best administration (in other words, the competent government).

The Korean government creates a consolidated system that provides information and services by integrating government bodies, domains and geographical jurisdictions into the process.

The following portals were created to provide services to citizens of the country: Electronic procurement system - www.g2b.go.kr, Electronic system for the provision of customs services www.portal.customs.go.kr, Electronic system of comprehensive tax services - www.hometax.go .kr, Electronic civil services - www.egov.go.kr, Electronic patent services - www.kiporo.go.kr, Online portal for applications and discussion of issues e-People - www.epeople.go.kr, Single window on business services - www.g4b.go.kr, System of Business Processes On-nara (Business Process System), Administrator Sharing implicit information - www.share.go.kr.

Thus, for the development of the digital sector in the analyzed countries, the skills of conducting indepth research and creativity became a competitive advantage. These countries, in their desire to develop the digital economy, create a digital infrastructure, form digital skills and strengthen cyber defense for the safe servicing of their citizens. All this creates a basis for successful digitization of the countries themselves.

At the same time, Kazakhstan does not start from scratch. In the 1990s, the state program on accelerated industrial and innovative development was launched, the international education program "Bolashak" was initiated, and in 2005 the formation of "e-government" was started. One of the steps to create conditions for the transition to an information society was the state program "Information Kazakhstan 2020", approved in 2013. As the basis for the digital transformation of the country's economy, 
this program contributed to the development of the following factors: the transition to an information society, the improvement of public administration, the creation of "open and mobile government" institutions, and the growth of accessibility of information infrastructure not only for corporate structures but for citizens of the country. The Head of State in his Address to the People of Kazakhstan on January 31, 2017 announced the Third Modernization, the core of which is digitalization, noted the need to cultivate new industries created using digital technologies, and that "it is important to ensure the development of communications, widespread access to fiber-optic infrastructure. The development of the digital industry will provide an impetus to all other industries. " In the fifth priority of the Third Modernization, the President of the country outlined the relevance of the fight against cybercrime, religious extremism and terrorism. In the Address of the Head of State, an instruction was sent to the Government and the National Security Committee to develop the concept of "Cybershield of Kazakhstan", whose goal is to ensure the information security of the society and the state in the field of information and communication, as well as protect the privacy of citizens when using their information and communication infrastructure.

The creation of e-government was necessary in order to make the work of government bodies more efficient, open and accessible to citizens. Previously, every state body "lived its own life" and had little contact with the rest, and citizens had to bypass many instances to collect all kinds of certificates, confirmations and other papers. All this turned the process of getting one service into endless walking through institutions. Now this is done, thanks to e-government projects.

E-government is a single mechanism for interaction between the state and citizens, as well as state bodies with each other, ensuring their coherence through information technology. It is this mechanism that made it possible to shorten queues to state bodies and simplify and speed up the receipt of certificates, certificates, permits and much more.

The idea of creating an e-government in our country was initiated by the head of state in the annual Message to the people of Kazakhstan on joining the republic among the fifty most competitive countries of the world. On November 10, 2004, the program on the introduction of e-government was approved by the Presidential Decree "On the State Program for the Formation of E-Government in the Republic of Kazakhstan for 2005-2007" (expired). The availability of electronic services has also been made possible through the provision of electronic digital signatures to citizens free of charge. To date, more than 10 million EDS have been issued in Kazakhstan, of which about 4.5 million are recorded on citizens' identity cards.

A single electronic document management system for government agencies (EDMS) using electronic digital signature technology was created and launched into commercial operation in April 2006. Interdepartmental electronic document management in Kazakhstan differs radically from the systems used in Europe or the countries of the post-Soviet space: it allows unifying the departmental systems of electronic document circulation of all central state bodies. EDMS is now applied in 80 central and 16 local executive bodies of the republic.

On April 12, 2006, the web portal of the "e-government of the Republic of Kazakhstan" was put into operation, which became a practical mechanism for access to information and interactive services of state bodies. To solve the main task of the portal - providing electronic services - software for integration modules with the unified EDMS and state databases, including "State Land Cadastre", "Integrated Tax Information System", "Physical, "Legal persons", "Address register", "Real estate register", database of the State Center for the payment of pensions.

According to the "State program for the formation of e-government in the Republic of Kazakhstan for 2005-2007", developed in view of world experience, the implementation of e-government in Kazakhstan envisages the following stages.

The first stage is informational. It was during this period that the e-government portal was launched and filled with information. Information appeared on the state bodies, their work and the services they provide to the population. In addition, the regulations for the provision of services were given and regulatory and legal acts were posted for familiarization.

At this stage, every Kazakh could get all the necessary information on the portal - a list of necessary documents, the size of the state duty, contact information of the state body, which you need to contact.

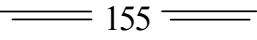


Already at the first stage, the running around the authorities and the number of visits were reduced, due to the provision of the full amount of necessary information.

The second stage - interactive, was marked by the launch of the provision of electronic services on the portal. Users of the portal have the opportunity to receive certificates from various institutions, without running through institutions and without losing time in queues, send a request to any government agency without leaving home and monitor its status. The introduction of interactive services on the e-government portal has allowed saving time on collecting the package of documents.

On November 30, 2007, the Resolution of the Government of the Republic of Kazakhstan No. 1155-1 "On Approving the Program for the Development of the" Electronic Government "of the Republic of Kazakhstan for 2008-2010" was abolished.

In accordance with this Government Decree, the formation of e-government was carried out according to the classical Western implementation scheme and consists of two circuits and three modules:

1. The internal loop regulates internal operations between state bodies through internal information channels. With a high level of information security, this connection is suitable for the transfer of sensitive information. This type of connection is called, as in the Western countries, the module "Government to Government" (government for government; G4G).

2. The external outline regulates relations between citizens, enterprises and the government and consists of two modules: "Government to Citizens" (G4C) and "Government to Business" (G4B).

It was at this stage that departmental information systems, state databases, electronic licensing and the electronic government gateway were introduced. In 2009, the introduction of the project "E-licensing", which is mainly intended for business entities, began. This is a simplification of procedures for obtaining by enterprises various licenses and permits for the implementation of licensed types of activities. Elicensing makes it possible for a person who applies for a license to track the entire procedure for its consideration. At the same time, contact between the person who is considering the application and the person who submits it is completely excluded. It has tremendous effectiveness in combating corruption.

The third stage in the development of e-government is transactional. To provide transactional "egovernment" services, an automated system "Payment gateway for e-government" was created for Internet payments, such as paying taxes, fines, penalties, etc. The payment gateway of "electronic government" is a kind of shop that allows user to make orders for public services and, accordingly, pay them by means of a payment card or from a current bank account. From the point of view of information exchange, the payment gateway of "e-government" directly interacts with the information system of acquiring banks, and those in turn - with the Kazakhstan Interbank Settlement Center and the Treasury system. The information on the payer and the details of his payment card will be reliably protected against various types of information hacking by means of their transmission through special communication channels.

In advanced economies, such as Sweden, Denmark, Norway, the United States, Singapore and others, the payment of public services by bank magnetic cards through Internet banking systems, through electronic e-cash systems of state electronic services, has long been a practice. In Kazakhstan, a similar project is being implemented for the first time.

For entrepreneurs, the transactional stage presented a truly valuable gift - electronic public procurement. The benefits are obvious - the transparency and openness of the competitions and tenders that have been held have increased. Henceforth, an entrepreneur, without leaving the office, can participate in tenders. Since January 1, 2010, all government purchases by means of requesting price proposals are made only in electronic format, on the web portal of state purchases www.goszakup.gov.kz. Thus, the portal successfully demonstrates the fulfillment of its main tasks: increasing the openness of the public procurement process, creating equal competition conditions, and reducing budget spending on the acquisition of goods and services.

The fourth stage of e-government is transformational; at this stage of development e-government is today. The main goal from now on is maximum efficiency in providing services to citizens. It is for the sake of achieving this goal that interactive and transactional services are combined into complex services, which the Kazakhstani population often needs. Users have the opportunity to register a legal entity in 15 minutes or register the birth of a child while simultaneously solving all the related issues - to apply for the assignment of benefits and put the child on the queue in the kindergarten. Special attention is paid to egovernment portal on socially-significant services, that's why all of them are translated into electronic format. 
During its existence, the e-government of the Republic of Kazakhstan has overcome four stages of formation and development; it was positively accepted and highly appreciated by the world community high positions in international and republican ratings, nominations in competitions testify to this. The degree of development of the Kazakh electronic government is estimated as "emerging" and is considered one of the most successful.

May 13, 2013 in Geneva, the results of the international competition WSIS Project Prizes 2013, this was held in the framework of the Forum of the World Summit on the Information Society. Electronic licensing system of Kazakhstan (www.elicense.kz) became the best project in the category "E-Business". More than 280 projects from 64 countries of the world took part in the competition. The success story of the project was published on the official resource of the International Telecommunication Union.

It should be noted that www.elicense.kz is an electronic system that allows you to receive various permits through the Internet. The idea of creating this tool, as a regulatory mechanism, monitoring in the field of permits, was born in 2008. Within the framework of this project, a lot of work was done to optimize the processes in the licensing area.

In particular, as a result of the inventory, the number of permits was reduced from 1035 to 517 . Integration with 27 information systems of state bodies allowed to abolish more than 600 types of documents that were previously required for obtaining permits and to shorten the terms for their issuance. We note that since August 2012 100\% of the license in Kazakhstan has been issued electronically. In July 2016, the World Economic Forum (WEF) report was published, according to which the Kazakhstan's network readiness index ranks 39th out of 139 countries. Compared to 2012 and the 55th position in the rating, the country shows a rapid growth in many parameters and is the best among the CIS countries. The network readiness index determines the level of development of information and communication technologies (ICT) in the country and consists of 54 indicators reflecting the contribution of ICT to the economy and the willingness of national economies to use these technologies.

Every two years, the United Nations Department of Economic and Social Affairs conducts studies to assess the level of development of e-government in the world. In 2012, the e-government of the Republic of Kazakhstan ranked 38th in this rating. At the same time, the index of online services grew by 10 positions, and the telecommunications infrastructure by 14 positions. According to the e-participation index, which determines the possibility of citizens' communication with the government, Kazakhstan took the second place, dividing it with Singapore. And in 2016, the electronic government of the Republic of Kazakhstan in this rating took 33 rd place. At the same time, the telecommunications infrastructure index climbed 1 position.

At the annual International Government Summit the World Government Summit, which was held in Dubai in February 2017. About four thousand prominent public and political figures, scientists and experts from 139 countries of the world, including from Kazakhstan, took part. The mobile application "Egov" was awarded the First World Govtechineers Race-2017 prize, as the best and most advanced mobile government application. Further, on June 13, 2017 in Geneva (Switzerland), in the framework of the Forum of the World Summit on the Information Society, the ceremony of awarding winners and champions of the international competition WSIS Prizes-2017 was held.

The international competition was conducted in 18 categories. In the e-government category, the eGovernment of Kazakhstan projects (eGov.kz), the Open Government (Open.egov.kz), in the category "The role of government and all stakeholders in promoting the use of ICT for development" The project "Single contact center 1414".

To be in the trend of modern technologies, the President of Kazakhstan NursultanNazarbayev initiated the state program "Digital Kazakhstan". Its main goal is to improve the quality of life of the population through the progressive development of the digital ecosystem and the competitiveness of Kazakhstan's economy.

Resolution of the Government of the Republic of Kazakhstan No. 827 of December 12, 2017 approved the State Program "Digital Kazakhstan" for 2017-2020. The implementation of the state program Digital Kazakhstan will be conducted in four key areas. The creation of the "Digital Silk Road" implies the development of a reliable, affordable, high-speed and secure digital infrastructure. Formation of the "Creative Society" will give impetus to the development of competencies and skills for the digital economy, will allow to work on increasing the digital literacy of the population and to train the sectoral 
ICT specialists. Digital transformations in the economic sectors will ensure the widespread introduction of digital technologies to enhance the competitiveness of various sectors of the economy. The formation of the "Proactive Digital Government" guarantees the possibility of improving the electronic and mobile government system, as well as optimizing the provision of public services.

\section{Conclusion}

Expected dividends for the country from the implementation of the state program "Digital Kazakhstan" are defined and identified in accordance with the strategic objectives of the state. First of all, we are talking about such important and relevant issues for the country as improving the efficiency and transparency of public administration, providing employment for the population, improving the quality of education and health, improving the investment climate, raising labor productivity and increasing the share of small and medium-sized businesses in the GDP structure. Economic experts estimated that as a result of the implementation of DP "Digital Kazakhstan", the share of the ICT sector (information and communication technologies) in GDP (gross domestic product) of Kazakhstan will reach $4.85 \%$ by 2020 , and labor productivity in this industry will grow by $31 \%$. Digital literacy of the population will be $80 \%$, the share of Internet users will increase to $78 \%$, and the percentage of e-government services rendered in relation to the total number of services received in paper and electronic forms will increase to $80 \%$.

In particular, Kazakhstan in the Doing Business rating of the World Bank in 2020 should be on the list of the first 35 countries. The index of "e-government" (according to the UN methodology) in 2020 should be among the first 25 countries. The availability of information and communication infrastructure in the households of the Republic of Kazakhstan should reach $100 \%$, and the number of Internet users in $2020-75 \%$.

As you know, the implementation of the state program is carried out in two stages - for 2013-2017 and 2018-2020. Within the first stage, the Government of the Republic of Kazakhstan approved the Action Plan for the implementation of the State Program "Information Kazakhstan 2020" for 2013-2017. As a result of the implementation of the program for 2013-2015, Kazakhstan in the Doing Business ranking of the World Bank in 2017 was in the list of the first 38 countries. The index of "e-government" (according to the UN methodology) in 2017 allowed to be among the first 30 countries. The share of households with access to the Internet, fixed telephony and mobile phones has increased. The volume of the Kazakhstani blogosphere, as well as the share of healthcare organizations connected to a single healthcare network, has increased - from $25 \%$ in 2014 to $91.5 \%$ in 2015 .

A new important stage in the development of the infrastructure for the provision of electronic services, taking into account the active penetration of mobile communications and mobile technologies among the population, is the creation of the Mobile Government. Now in Kazakhstan through the mobile application eGov for platforms iOS, Android and Windows Phone you can get 80 different services and services.

\section{REFERENCES}

[1] Fedoseeva N.N. Concept and essence of the concept of an electronic state // Russian Justice. 2011. No. 11. P. 6-10.

[2] Tikhonova S.V. Branches of power in the electronic state // Bulletin of the Saratov State Law Academy. 2013. No. 3 (92). P. 11-16.

[3] Chebotarev V.E, Konovalova E.I. Electronic state, e-government, e-democracy at the present stage of the development of the Russian Federation // The legal world. 2012. No. 7. P. 35-38.

[4] Kovaleva N.N. The correlation between the terms "electronic state" and "electronic government" // Bulletin of the Saratov State Law Academy. 2011. No. 6. P. 106-109.

[5] Azizov R.F. Electronic government as an element of an electronic state // Scientific works of the Russian Academy of Advocacy and Notary. 2014. No. 4 (35). P. 22-27.

[6] Kusainov, D.O. and D.A. Ospanova, 2012. Improvement of the Institute of the Republic of Kazakhstan. European Science and Technology: materials of the III international research and practice conference, Vol. II, Munich, October 30 th- - 31 , 2012. / publishing office Vela VerlagWaldkraiburg. Munich. Germany. pp: 243-246.

[7] Message from the President of the Republic of Kazakhstan N.A. Nazarbayev to the people of Kazakhstan on March 19, 2004 "Towards a Competitive Kazakhstan, Competitive Economy, Competitive Nation" // http://www.akorda.kz/en/addresses/addresses of president/poslanie-prezidenta-respubliki-kazakhstan-na-nazarbaeva-narodu kazakhstana-19-mart-2004-g 1342416361

[8] Decree No. 1471 of the President of the Republic of Kazakhstan of November 10, 2004 "On the State Program for the Formation of" Electronic Government "in the Republic of Kazakhstan for 2005-2007" (lost force) // https://online.zakon.kz/Document/?doc_id = 1051540

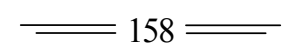


[9] Law of the Republic of Kazakhstan dated January 7, 2003 No. 370-II "On electronic document and electronic digital signature" (with changes and additions as of December 28, 2017) // https://online.zakon.kz/Document /?doc_id = 1035484

[10]Resolution of the Government of the Republic of Kazakhstan dated November 30, 2007 No. 1155-1 "On approval of the Development Program for" e-government "of the Republic of Kazakhstan for 2008-2010" (lost force) // https://online.zakon.kz/Document/?doc_id $=30154572$

[11]What is electronic government and what is it for? // http: //egov.kz/cms/ru/information/about/help-elektronnoepravitelstvo

[12]Kazakhstan project "E-licensing" is recognized as the best in the competition WSIS Project Prizes 2013 // http: //profit.kz/news/9704/Kazahstanskij-proekt-E-licenzirovanie-priznan-luchshim-v-konkurse-WSIS-Project-Prizes-2013

[13]Kazakhstan participates in The World Government Summit in Dubai // https://forbes.kz/news/2017/02/13/newsid_135389

[14]Prize-2017 Champions Awards ceremony // https://www.nitec.kz/story/nagrajdenie-chempionov-wsis-prizes-2017

[15]Resolution of the Government of the Republic of Kazakhstan No. 827 of 12 December 2017 on the approval of the State Program "Digital Kazakhstan" // https://primeminister.kz/en/page/view/

УДК 342.7(574)

\section{Д.А. Оспанова, Д.М. Баймаханова}

Казахский Национальный университет имени аль-Фараби, г.Алматы

\section{АДМИНИСТРАТИВНО-ПРАВОВОЕ ОБЕСПЕЧЕНИЕ ЦИФРОВИЗАЦИИ ГОСУДАРСТВЕННЫХ УСЛУГ В УСЛОВИЯХ РАЗВИТИЯ КИБЕР ПРОНСТРАНСТВА РЕСПУБЛИКИ КАЗАХСТАН}

Аннотация: Целью работы является анализ правовых нюансов развития электронного правительства в Республике Казахстан; определение периодизации развития формирования и деятельности электронного правительства; определение особенностей электронного документооборота посредством электронного правительства. Актуальность статьи обусловлена следующими факторами: ускорение процессов цифровой модернизации в Казахстане под влиянием глобальной информатизации ведет к переходу к электронному документообороту; повышение эффективности казахстанского правительства за счет внедрения информационных технологий; необходимость разработки государственной политики в области применения новых технологий во всех сферах жизнедеятельности (НАО «Государственная корпорация «Правительство для граждан»); необходимость ускорить экономическую и политическую модернизацию казахстанского общества посредством широкого использования информационных технологий, а также теоретический и практический интерес к изучению потенциальных преимуществ электронного правительства и электронного документооборота.

Ключевые слова: портал электронного правительства, электронное правительство, электронная цифровая подпись, электронный документооборот.

Information about authors:

Ospanova D.A. - candidate of law, associate professor of chair of the theory and history of state and law, constitutional and administrative law, law department, al-Farabi Kazakh National University, Republic of Kazakhstan, Almaty, E-mail: azizkhan_0606@mail.ru; https://orcid.org/0000-0001-7561-6596;

Baimakhanova D.M. - doctor of law, professor of chair of the theory and history of state and law, constitutional and administrative law, law department, al-Farabi Kazakh National University, Republic of Kazakhstan, Almaty, E-mail: dina_405@mail.ru, https://orcid.org/0000-0002-2741-4348 


\section{МАЗМҰНЫ}

Алтыбаева С.М., Савындыков Е.С. Көркем мәтін құрылымындағы мифопоэтикалық модельдеу және мәдени код...... 5 Сембиева Л.М., Мажитов Д.М., Карпиикая М.Е., Хамитова Д.М. Экономиканы жаңғырту жағдайындағы ЕАЭО елдерінің монетарлық жүесінін өзгеруі .....

Құлсариева А.Т., Султанова М.Э., Шайгозова Ж.Н. Фольклор және сәйкестілік: Қазақстанның қазіргі заманғы

мәдениетіндегі тарих, жады және аңыз шығармашылығы ........................................................................................... 19

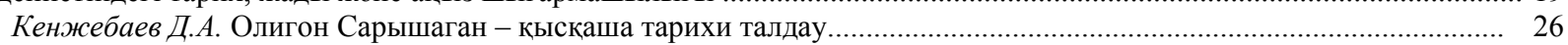

АбдулинаГ.А., БазарбаевА.Г. Ұйымдардағы адам ресурстарын басқарудың заманауи тұжырымдамалары................ 33

Авыбаев А.Н., Адибаева А.К. Геноцид туралы БҰҰ Конвенциясының қатысушы мемлекеттердің қылмыстық

заңнамаларындағы имплементациялық тетіктері: жалпы салыстырмалы талдау............................................................ 39

Ахметжанов Б., Тәжібекова К.Б., Шаметова А.А. Қазақстан көлік өнеркәсіптің дамуын талдау............................. 44

Аюпова 3.К., Құсайынов Д.Ө. Тәуелсіздік жағдайындағы қазақстан республикасының конституциялық-құқықтық

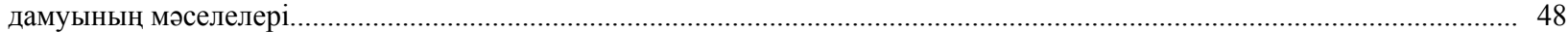

Нурпеисова А.А., Рей И.Ю., Бижанов Д.Т., Тлеужанова Д.А. Инновациялық өндірісді жасаудың процесін

бақылауының негізгі элементтері

Гиздатов Г.Г. Қазақстандық дискурсының құрылымы психолингвистиякалық зерттеу .

Ищанова Р.К. Мемлекеттік шығындарды басқару - мемлекеттің қаржылық тұрақтылығын қамтамасыз ету.............. 64

Мадышева А.М. Бикенова А.С., Елеусиз Л.Т. Білім саласындағы туристік қызметтер............................................. 68

Ескалиева А. Ж., Баймуханова М.Т., Ахмурзина Д.О. Әлеуметтік сала адам капиталының сапасын қолдаудың

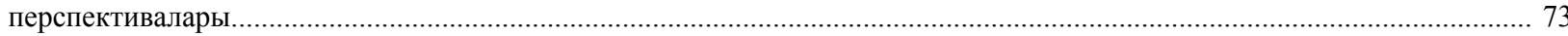

Мархаева Б.А., Козбахова Д.Л. Жауапкершілік орталық және трансферттік баға белгілеу............................................ 79

Сабирова Р.К., Утепкалиева К.М., Кабаков С.Б. Қазақстандағы ауыл шаруашылығы экономикасының

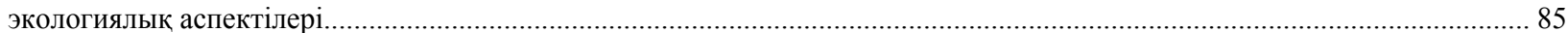

Тлесова Э., Хойч А., Кураш Н. Қазақстан республикасының ғылыми инновациялық потенциясы және оның

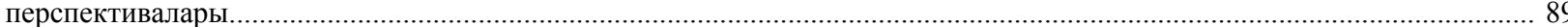

Хамитхан Н. Қазақстандағы банктік қызметтердің сапасын жақсарту жағдайында банкаралык басекелестік............ 95

Шалдарбеков Қ.Б., Муханова Г.С., Нурмухамбетова 3.С. Аймақтарды дамыту бағдарламаларын жүзеге асырудағы жобалық басқаруды қолданудың шетелдік тәжірибесі

КаратаеваА.М., Бердиярова Ж.С. Мемлекеттік қызметшінің әдептік мәдениеті және құқықтық мәдениеті

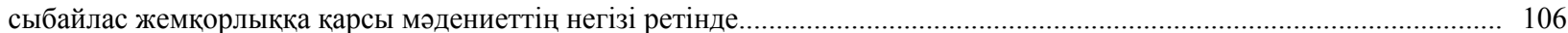

Алдабергенова А.А. Абсурд әдебиетін аударудың лингвомәдени аспектілері ................................................... 113

Стукач В. Ф., Байдалинова А. С., Сандыбаева Б. А. Қазақстанның қаржылық қауіпсіздігі......................................... 119

Баймаханова Д.М., Оспанова Д.А. Конституциялық-құқықтық сана - конституционализмнің маңызды

компоненті ретінде және оның адам құқықтары мәселелерін шешудегі рөлі................................................................. 126

Имангожина 3.А. Сланцевая революция: глобальный тренд на мировом энергетическом рынке............................. 137

Ракаева А.Н., Жуматаева Б.А., Успамбаева М.К., Доскалиева Б.Б. Экологиялық есеп қазақстандағы кәсіпорын экономикасының даму кезеңі ретінде

Нуржанова Г.И. Экономиканың аграрлық секторындағы еңбек әлеуетіне демографиялық фактордың әсері............ 147

Оспанова Д.А., Баймаханова Д.М. Қазақстан Республикасының кибер кеңістігін дамыту жағдайында мемлекеттік қызметтерді цифрландыруда әкімшілік-құқықтық қамтамасыз ету ................................................................................... 152

Pblсnекова М.О., Тлесова Э.Б., Хаитбаева Ф.К. Қазақстандағы тұрғын үй-коммуналдық шаруашылық қызметін

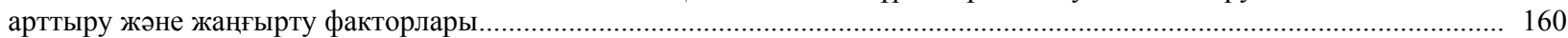

Султанова Г. Т. Аграрлық сектордың экспорттық әлеуетін дамытуға бағытталған үрдістер мен басымдықтар........ 166 


\section{СОДЕРЖАНИЕ}

Алтыбаева С.М., Сагындыков Е.С. Культурный код и мифопоэтическое моделирование в структуре художественного текста.

Сембиева Л.М., Мажитов Д.М., Карпиикая М.Е., Хамитова Д.М. Трансформация монетарной системы стран

ЕАЭС в условиях модернизации экономики.............................................................................................................

Кулсариева А.T., Султанова М.Э., Шайгозова Ж.Н. Фольклор и идентичность: история, память и мифотворчество

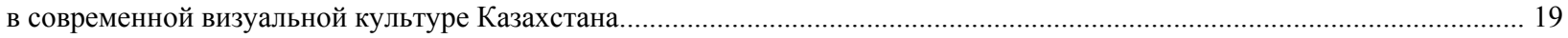

Кенжебаев Д.А. Полигон Сарышаган - краткий исторический анализ................................................................ 26

Абдулина Г.А., БазарбаевА.Г. Современные концепции управления человеческми ресурсами в организациях........... 33

Агыбаев А.Н., Адибаева А.К. Имплементационные механизмы Конвенции ООН о геноциде в уголовных

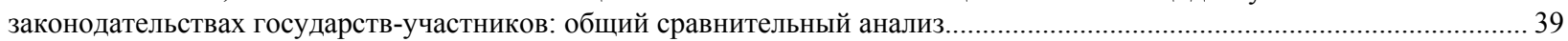

Ахметжанов Б., Тажибекова К.Б., Шаметова А.А. Анализ развития угольной промышленности Казахстана........... 44

Аюпова 3.К., Кусаинов Д.У.Проблемы конституционно-правового развития республики Казахстан в условиях

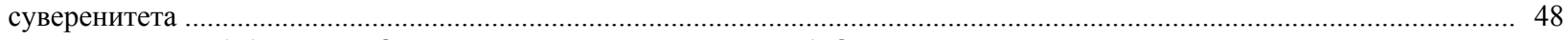

Нурпеисова А.А., Рей И.Ю., Бижанов Д.Т., Тлеужанова Д.А. Основные элементы управления процессом создания

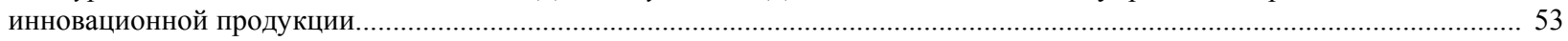

Гиздатов Г.Г. Психолингвистическое исследование концептов казахстанского дискурса...................................... 57

Ищанова Р.К. Управление государственными расходами - как обеспечение финансовой устойчивости государства. 64

Мадымева А.М. Бикенова А.С., Елеусиз Л.Т. Туристские услуги в сфере образования........................................... 68

Ескалиева А. Ж., Баймуханова М.Т., Ахмурзина Д.О. Перспективы усиления качества человеческого капитала

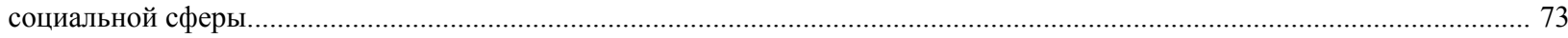

Мархаева Б.А., Козбахова Д.Л. Центр ответственности и трансфертное ценообразование..................................... 79

Сабирова Р.К., Утепкалиева К.М., Кабаков С.Б. Экологические аспекты экономики сельского хозяйства

в Казахстане........................................... 85

Тлесова Э., Хойч А., Кураш Н. Научно-инновационный потенциал республики Казкастан и его перспективы............ 89

Хамитхан Н. Межбанковская конкуренция в условиях повышения качества банковских услуг в Казахстане.............. 95

Шалдарбеков К.Б., Муханова Г.С., Нурмухамбетова 3.С. Зарубежный опыт применения проектного управления

при реализации программ развития регионов

Каратаева А.М., Бердиярова Ж.С. Этическая культура и правовая культура государственных служащих

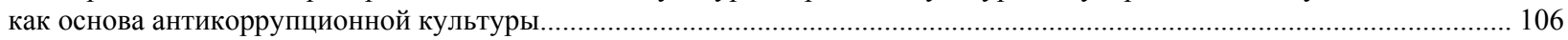

Алдабергенова А.А. Лингвокультурологические аспекты перевода литературы абсурда.......................................... 113

Стукач В. Ф., Байдалинова А. С., Сандыбаева Б. А. Казахстанская финансовая безопасность.................................... 119

Баймаханова Д.М., Оспанова Д.А. Конституционно-правовое сознание как важный компонент конституционализма

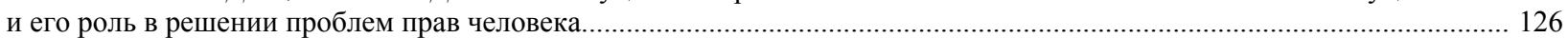

Имангожина 3.A. Сланцевая революция: глобальный тренд на мировом энергетическом рынке............................. 137

Ракаева А.Н., Жуматаева Б.А., Успамбаева М.К., Доскалиева Б.Б. Экологический учет как ступень развития

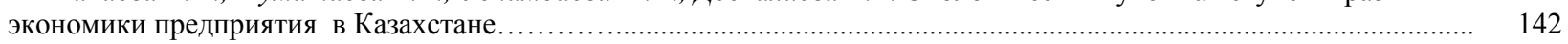

Нуржанова Г.И. Влияние демографического фактора на трудовой потенциал аграрного сектора экономики............ 147

Оспанова Д.А., Баймаханова Д.М. Административно-правовое обеспечение цифровизации государственных услуг

в условиях развития кибер пронстранства республики Казахстан..

Pыспекова М.О., Тлесова Э.Б., Хаитбаева Ф.К. Факторы инновационной модернизации и совершенствования

деятельности жилищно-коммунального хозяйства в Казахстане.

160

Султанова Г. Т. Тенденции и приоритеты развития экспортного потенциала аграрного сектора................................ 166 


\section{CONTENTS}

Altybayeva S.M., Sagyndykov E.S. Cultural code and myth poetic modeling in the structure of the artistic text..................... 5 Sembiyeva L.M., Mazhitov D.M., Karpitskaya M.E., Khamitova D.M. Transformation of the monetary system of the eurasian economic UNION countries in the conditions of modernization of the economy......

Kulsarieva A.T., Sultanova M.E., Shaigozova Zh.N. Folklore and identity: history, memory and myth-making in the modern

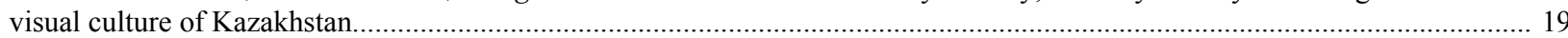

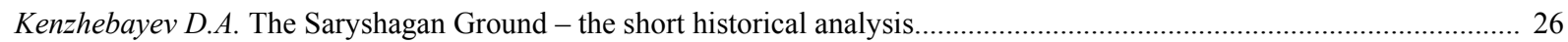

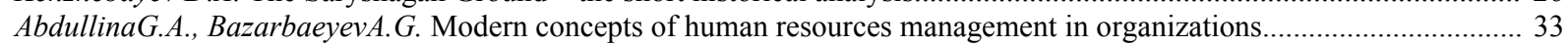

Agybayev A.N., Adibayeva A.K. Implementing mechanisms of the UN Convention on genocide in the criminal legislation

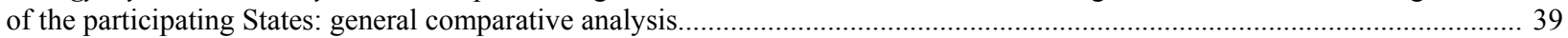

Akhmetzhanov B., Tazhibekova K.B, Shametova A.A. Analysis of development of the coal industry of Kazakhstan.............. 44 Ayupova Z.K., Kussainov D.U. Problems of constitutional and legal development of the republic of kazakhstan in the conditions of sovereignty......

Nurpeisova A.A., Rey I.Yu., Bizhanov D.T., Tleuzhanova D.A. Main elements of managing the process of creating innovation production.

Gizdatov G.G. Psycholinguistic study of the concepts of Kazakhstar

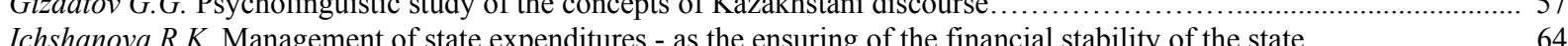

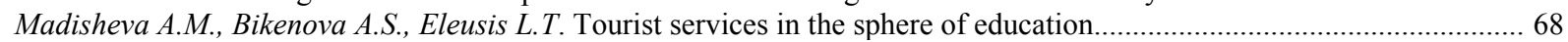

Eskalieva A. Zh., Baymukhanova M.T., Ahmurzina D.O. Perspectives of strengthening the quality of the human capital

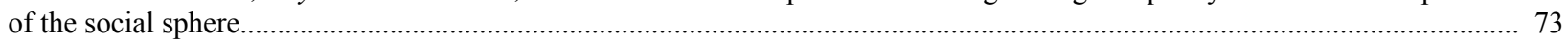

Markhayeva B.A., Kozbakhova D.L. A responsibility center and transfer pricing ................................................. 79

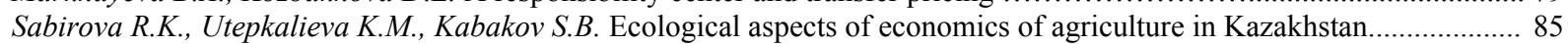

Tlessova E., Khoich A., Kurash N. Scientific innovation potential of the republic of Kazkahstan and its perspectives........ 89

Hamitkhan $N$. Interbank competition in conditions of improving the quality of banking services in Kazakhstan.................. 95

Shaldarbekov K., Mukhanova G., Nurmukhambetova Z. International practices in project management in implementing

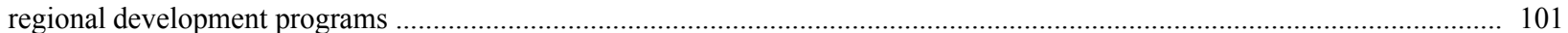

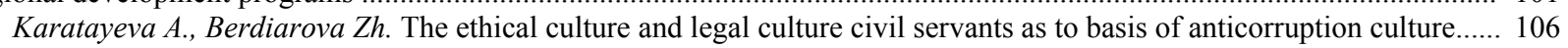

Aldabergenova A.A. Linguocultural aspects of translation of absurd literature.............................................................. 113

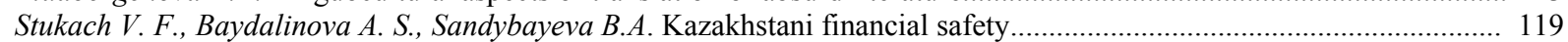

Baimakhanova D.M., Ospanova D.A. Constitutional and legal consciousness as an important component of constitutionalism

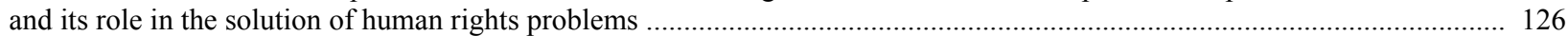

Imangozhina Z.A. Shale gas revolution: global trend in the world energy market..................................................... 137

Rakaeva A.N., Zhumataeva B.A., Uspanbayeva M.K., B.B.Doskalieva. Level of ecological report development in the economic of Kazakhstan's companies.

Nurzhanova G.I. Impact of demographic factors on labor potential of economy's agricultural sector

Ospanova D.A., Baimakhanova D.M. Administrative and legal support of digitalization of public services in the context of the development of cyber space in the republic of Kazakhstan....

Ryspekova M.O., Tlessova E.B., Khaitbayeva F. Factors of innovative modernization and improvement of activity

of housing and communal services in Kazakhstan.

Sultanova G. T. Trends and priorities for the development of export potential of the agrarian sector. 


\title{
PUBLICATION ETHICS AND PUBLICATION MALPRACTICE IN THE JOURNALS OF THE NATIONAL ACADEMY OF SCIENCES OF THE REPUBLIC OF KAZAKHSTAN
}

For information on Ethics in publishing and Ethical guidelines for journal publication see http://www.elsevier.com/publishingethics and http://www.elsevier.com/journal-authors/ethics.

Submission of an article to the National Academy of Sciences of the Republic of Kazakhstan implies that the work described has not been published previously (except in the form of an abstract or as part of a published lecture or academic thesis or as an electronic preprint, see http://www.elsevier.com/postingpolicy), that it is not under consideration for publication elsewhere, that its publication is approved by all authors and tacitly or explicitly by the responsible authorities where the work was carried out, and that, if accepted, it will not be published elsewhere in the same form, in English or in any other language, including electronically without the written consent of the copyrightholder. In particular, translations into English of papers already published in another language are not accepted.

No other forms of scientific misconduct are allowed, such as plagiarism, falsification, fraudulent data, incorrect interpretation of other works, incorrect citations, etc. The National Academy of Sciences of the Republic of Kazakhstan follows the Code of Conduct of the Committee on Publication Ethics (COPE), and follows the COPE Flowcharts for Resolving Cases of Suspected Misconduct (http://publicationethics.org/files/u2/New Code.pdf). To verify originality, your article may be checked by the originality detection service Cross Check http://www.elsevier.com/editors/plagdetect.

The authors are obliged to participate in peer review process and be ready to provide corrections, clarifications, retractions and apologies when needed. All authors of a paper should have significantly contributed to the research.

The reviewers should provide objective judgments and should point out relevant published works which are not yet cited. Reviewed articles should be treated confidentially. The reviewers will be chosen in such a way that there is no conflict of interests with respect to the research, the authors and/or the research funders.

The editors have complete responsibility and authority to reject or accept a paper, and they will only accept a paper when reasonably certain. They will preserve anonymity of reviewers and promote publication of corrections, clarifications, retractions and apologies when needed. The acceptance of a paper automatically implies the copyright transfer to the National Academy of sciences of the Republic of Kazakhstan.

The Editorial Board of the National Academy of sciences of the Republic of Kazakhstan will monitor and safeguard publishing ethics.

Правила оформления статьи для публикации в журнале смотреть на сайте:

$$
\begin{gathered}
\text { www:nauka-nanrk.kz } \\
\text { social-human.kz }
\end{gathered}
$$

\author{
Редакторы М.С. Ахметова, Т.А. Апендиев, Д.С. Аленов \\ Верстка на компьютере А.М. Кульгинбаевой \\ Подписано в печать 10.10.2018 \\ Формат 60x881/8. Бумага офсетная. Печать - ризограф. \\ 11,6 п.л. Тираж 500. Заказ 5.
}

